\title{
Propolis as a potential alternative for the control of Dekkera bruxellensis in bioethanol fermentation
}

\section{Própolis como alternativa potencial para o controle de Dekkera bruxellensis em fermentação alcoólica}

\author{
Leticia Andrea Fernández ${ }^{1 *}$; Irene Laura Cibanal2; Anna Livia Paraluppi ${ }^{3}$; \\ Caroline de Freitas ${ }^{4}$; Liliana María Gallez ${ }^{5}$; Sandra Regina Ceccato-Antonini ${ }^{6}$
}

\begin{abstract}
Dekkera bruxellensis is one of the most important contaminant yeasts of alcoholic fermentation. The use of propolis, which can selectively target contaminating yeasts without affecting the starter one, Saccharomyces cerevisiae, could be a useful nonconventional strategy for controlling the growth of contaminant yeasts. The objective of this research was to evaluate four samples of propolis produced by Apis mellifera honeybees from different regions of Argentina as antimicrobial agents against the growth of $D$. bruxellensis and $S$. cerevisiae. Hydroalcoholic extracts of propolis were prepared with ethanol:water $(70: 30 \mathrm{v} / \mathrm{v})$, and the specific absorbance and final concentration of the samples were evaluated. A qualitative in vitro assay in solid medium was performed with different propolis concentrations, and the evaluation of yeast growth was based on a qualitative scale. A quantitative in vitro assay in liquid medium was also performed to assess the yeast cell number, using two different propolis concentrations. The cell number of D. bruxellensis decreased 1.52 and $1.85 \log$ cycles with the two propolis extracts utilised at a concentration of $4.5 \mathrm{mg} \mathrm{mL}^{-1}$ while the cell number of $S$. cerevisiae decreased 0.48 and $0.76 \log$ cycles with the same samples of propolis. The results from both assays demonstrated the selectivity of propolis use on the yeast species, leading to a higher inhibition of $D$. bruxellensis growth. This indicates a good potential for using propolis at the concentration of $4.5 \mathrm{mg}$ $\mathrm{mL}^{-1}$, as a nonconventional strategy to control the growth of $D$. bruxellensis without significantly affecting $S$. cerevisiae, the yeast starter of ethanol fermentation.
\end{abstract}

Key words: Apis mellifera honeybees. Antimicrobial activity. Hydroalcoholic extracts. Argentina. Saccharomyces cerevisiae.

\section{Resumo}

Dekkera bruxellensis é uma das mais importantes leveduras contaminantes da fermentação alcoólica. O uso de própolis, que pode seletivamente afetar a levedura contaminante mas não a levedura do processo,

\footnotetext{
1 Laboratorio de Estudios Apícolas, Universidad Nacional Del Sur, UNS, Bahía Blanca, Bs. As., Argentina. E-mail: lafernan@uns. edu.ar

2 Doctoral Student, Laboratorio de Estudios Apícolas, Universidad Nacional Del Sur, UNS, Bahía Blanca, Bs. As., Argentina. E-mail: pilicibanal@gmail.com

3 Discente, Curso de Mestrado do Programa de Pós-Graduação em Produção Vegetal e Bioprocessos Associados, Universidade Federal de São Carlos, UFSCar, Araras, SP, Brasil. E-mail: paraluppiannal@gmail.com

4 Discente do Curso de Graduação em Biotecnologia, UFSCar, Araras, SP, Brasil. E-mail: caroline.fr94@gmail.com

5 Prof ${ }^{a}$, Universidad Nacional Del Sur, Laboratorio de Estudios Apícolas, UNS, Bahía Blanca, Bs. As., Argentina. E-mail: 1gallez@ uns.edu.ar

6 Prof ${ }^{\text {a }}$, Laboratório de Microbiologia Agrícola e Molecular, UFSCar, Araras, SP, Brasil. E-mail: antonini@ufscar.br

* Author for correspondence
} 
Saccharomyces cerevisiae, pode ser uma estratégia não convencional útil para o controle de leveduras contaminantes. O objetivo deste trabalho foi avaliar quatro amostras de própolis produzidas por Apis mellifera de diferentes regiões da Argentina como agentes antimicrobianos no controle do crescimento de D. bruxellensis e $S$. cerevisiae. Foram preparados extratos hidroalcoólicos de própolis com etanol: água $(70: 30 \mathrm{v} / \mathrm{v})$ e avaliadas a absorbância específica e concentração final das amostras. Um ensaio qualitativo in vitro foi realizado em meio sólido com diferentes concentrações de própolis e a avaliação do crescimento da levedura foi baseada em uma escala qualitativa. Um ensaio quantitativo in vitro em meio líquido foi realizado com duas concentrações de própolis, avaliando-se o número de leveduras. $\mathrm{O}$ número de células de $D$. bruxellensis diminuiu 1,52 e 1,85 ciclos log com dois extratos de própolis na concentração de $4,5 \mathrm{mg} \mathrm{mL}^{-1}$ enquanto para $S$. cerevisiae, a diminuição no número de células foi de 0,48 e 0,76 ciclos log com as mesmas amostras de própolis. Os resultados de ambos os ensaios demonstraram claramente a seletividade do efeito do emprego de própolis nas leveduras estudadas, resultando em maior inibição no crescimento da levedura $D$. bruxellensis. Isso indica a boa perspectiva do uso de própolis, na concentração de $4,5 \mathrm{mg} \mathrm{mL}^{-1}$, como uma estratégia não convencional para controlar o crescimento de D. bruxellensis sem afetar substancialmente $S$. cerevisiae, a levedura agente da fermentação etanólica.

Palavras-chave: Abelhas Apis mellifera. Atividade antimicrobiana. Extratos hidroalcoólicos. Argentina. Saccharomyces cerevisiae.

Dekkera bruxellensis is commonly cited as one of the most important contaminant yeasts of alcoholic fermentations, especially in Brazilian industrial setups. This yeast has been responsible for several episodes of contamination in fermentation processes in distilleries in the United States, Canada, Europe and in the Northeast region of Brazil. The species D. bruxellensis replaced the initial Saccharomyces cerevisiae strains during one harvesting season and reached levels of almost $50 \%$ of the total yeast population. The ethanol productivity of $D$. bruxellensis isolates are much lower than that of $S$. cerevisiae and impaired the global ethanol yield of the distillery (SOUZA-LIBERAL et al., 2007). Low sugar consumption, low alcohol production and expressive growth were found in bioethanol fermentation contaminated with $D$. bruxellensis in batch systems (MENEGHIN et al., 2013).

Antimicrobials such as sulphur dioxide, chitosan and dimethyl dicarbonate have been utilised to control populations of this undesirable yeast in wine (BARATA et al., 2008; GÓMEZ-RIVAS et al., 2004). However, the continued administration of these products can lead to the creation of resistant strains, raise processing costs and allow the incorporation of residues in the product, lowering the beverage quality. In addition, acid cell washing is occasionally inefficient, and the corrosive acids are a serious safety risk. Strategies to control the growth of $D$. bruxellensis in the bioethanol industry are scarce (BASSI et al., 2013, 2014). Thus, new antimicrobials should be researched and tested. Among them, natural products can be considered as nonconventional strategies to control yeast growth in the bioethanol industry. Propolis is an example of an animal-derived natural product with good potential in controlling bacterial contamination (CECCATO-ANTONINI, 2018).

Propolis is an extremely complex, resinous substance collected by honeybees from buds and tree leaves, mixed with pollen and enzymes. It contains a variety of chemical compounds, such as flavonoid aglycones, phenolic acids and their esters, phenolic aldehydes, alcohols and ketones, sesquiterpenes, quinones, coumarins, steroids, aminoacids, and inorganic compounds (VIUDA-MARTOS et al., 2008). The composition is quite variable, depending on the origin of the samples, which is strongly related to the flora surrounding the hive (SFORCIN; BANKOVA, 2011). The antibacterial and antifungal properties are the most popular and extensively investigated biological activities of propolis, with many applications in medicine, cosmetology, the food industry, agriculture, etc. (VIUDA-MARTOS et al., 2008). Studies have demonstrated the antimicrobial effect of propolis against bacteria in alcoholic fermentation for fuel production, both using hydroalcoholic and oily extracts (BADIN, 
2010). However, the effect of propolis on the growth of native (wild) yeasts, such as D. bruxellensis, has not yet been reported.

Propolis has been utilised as a biological alternative for the control of phytopathogenic fungi (GALLEZ et al., 2014, 2017). In this work, we proposed to study propolis as a new nonconventional method to control a contaminant yeast in ethanolic fermentations. We hypothesised that it would be possible to use propolis as an antimicrobial agent that can selectively target the contaminating yeast without affecting the starter one, S. cerevisiae. The aim of this work was to evaluate four propolis samples as antimicrobial agents on the growth of D. bruxellensis and S. cerevisiae. Qualitative and quantitative assessments were carried out in vitro with propolis samples from Argentinean apiaries.

In this study, four samples of raw propolis produced by Apis mellifera honeybees were collected from apiaries located in different regions of Argentina (Figure 1): 1) Río Colorado, Río Negro Province, $\left(36^{\circ} 09^{\prime} 02^{\prime \prime} \mathrm{S}\right.$ and $\left.70^{\circ} 23^{\prime} 47^{\prime \prime} \mathrm{W}\right)$; 2) Luján de Cuyo, Mendoza Province ( $33^{\circ} 01^{\prime} \mathrm{S}$ and $\left.68^{\circ} 52^{\prime} \mathrm{W}\right)$; 3) Bahía Blanca, Buenos Aires Province $\left(38^{\circ} 43^{\prime} \mathrm{S}\right.$ and $62^{\circ} 16^{\prime} \mathrm{W}$ ); and 4) Carmen de Patagones, Buenos Aires Province $\left(40^{\circ} 47^{\prime} \mathrm{S}\right.$ and $\left.62^{\circ} 58^{\prime} \mathrm{W}\right)$. Propolis were collected with propolis traps, minimising the contamination with foreign substances, and stored at $-20^{\circ} \mathrm{C}$. The hydroalcoholic extracts of the propolis samples were prepared as described in Gallez et al. (2014). Briefly, $15 \mathrm{~g}$ of propolis were extracted in a flask with $150 \mathrm{~mL}$ of ethanol:water $(70: 30 \mathrm{v} / \mathrm{v})$ for $24 \mathrm{~h}$ at room temperature $\left(\sim 30^{\circ} \mathrm{C}\right)$ with shaking prior to use. The specific absorbance was determined in an UV spectrophotometer (JASCO V-630 BIO), as well as the final concentration $\left(\mathrm{mg} \mathrm{mL}^{-1}\right)$ of soluble compounds of each propolis sample, which were obtained from the hydroalcoholic extracts according to Bedascarrasbure et al. (2006).

Figure 1. Map of Argentina with the collection sites of propolis and the respective UV-VIS spectra from the hydroalcoholic extracts (range from 240 to $420 \mathrm{~nm}$ ). 1. Río Colorado, Río Negro Province; 2. Luján de Cuyo, Mendoza Province; 3. Bahía Blanca, Buenos Aires Province and 4. Carmen de Patagones, Buenos Aires Province.

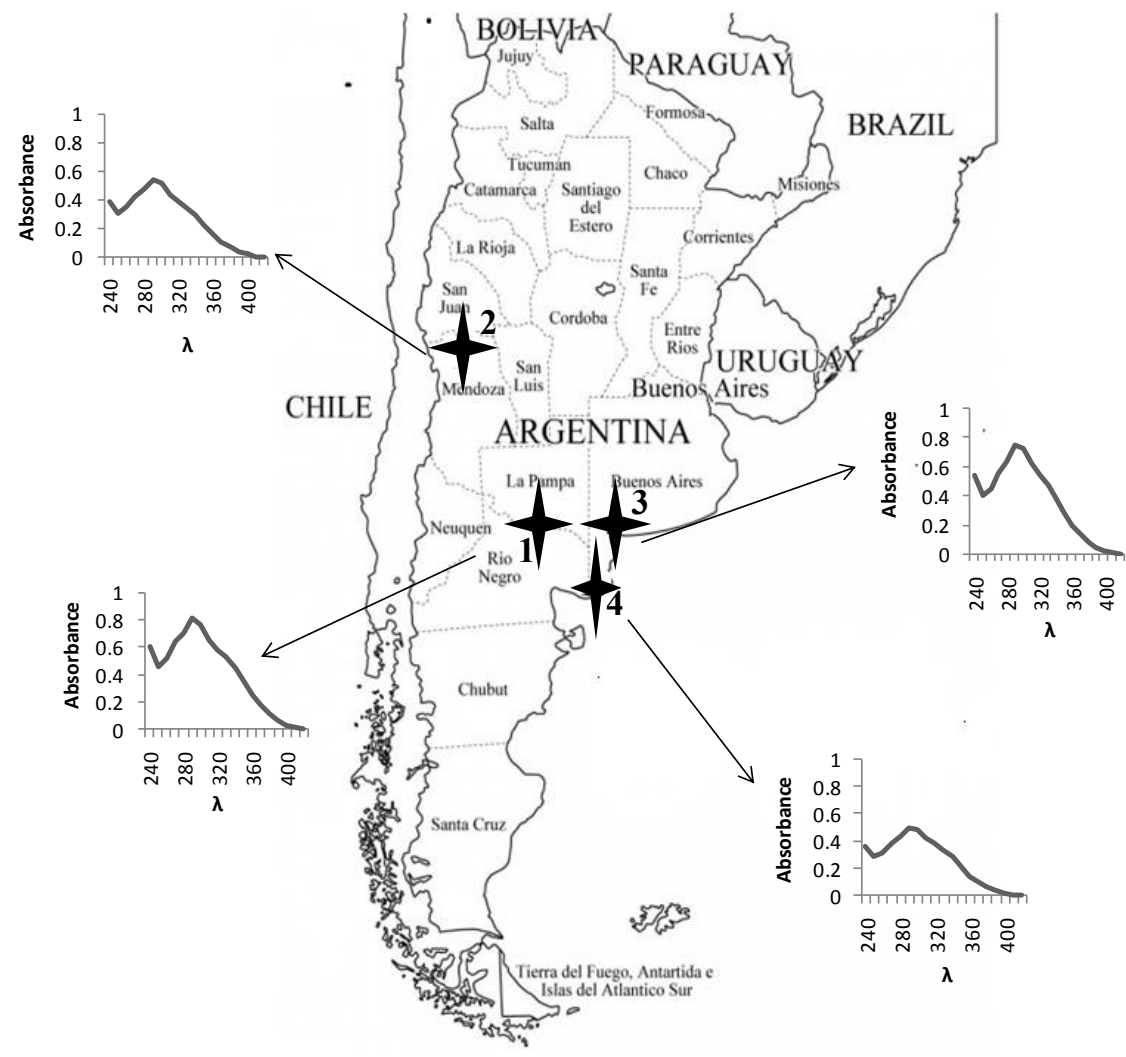


D. bruxellensis strain CCA155 (CCT7784), isolated from a Brazilian industrial alcoholproducing unit, and $S$. cerevisiae strain $\mathrm{PE}-2$, the most common starter yeast utilised in fermentation processes for fuel ethanol production, were both grown in YPD broth ( $2 \%$ glucose, $1 \%$ yeast extract and $2 \%$ bacteriological peptone in distilled water) until an optical density at $600 \mathrm{~nm}$ of 0.45 and 0.75 (approximately $10^{7} \mathrm{UFC} \mathrm{mL}^{-1}$ each) were obtained for each yeast, respectively. These yeast suspensions were utilised as inocula.

The qualitative in vitro assay was performed in Petri dishes, where YPD was mixed with each hydroalcoholic extract of propolis to obtain final concentrations of $0.1125,0.225,0.45$ and $0.9 \mathrm{mg}$ $\mathrm{mL}^{-1}$ of propolis in a final volume of $20 \mathrm{~mL}$ of medium per Petri dish. The yeast cell suspensions were diluted $\left(10^{-1}, 10^{-3}\right.$ and $\left.10^{-5}\right)$, and 3 drops (10 $\mu \mathrm{L} / \mathrm{drop})$ were plated employing a modification of the drop plate method described by Herigstad et al. (2001). Four plates per propolis sample and concentration were performed. Plates with only YPD or with YPD without propolis but containing ethanol:water $(70: 30 \mathrm{v} / \mathrm{v})$ were used as control. All Petri dishes were incubated at $30^{\circ} \mathrm{C}$ for $48 \mathrm{~h}$. The evaluation of yeast growth was based on a qualitative scale.

Two hydroalcoholic extracts of propolis were selected for the quantitative in vitro assay, which was performed according to Bassi et al. (2014) with some modifications. Briefly, $50 \mathrm{~mL}$ Falcon tubes containing a final volume of $10 \mathrm{~mL}$ were prepared with $7.5 \mathrm{~mL}$ of YPD broth, $1 \mathrm{~mL}$ of yeast suspension (as described above) and 0.75 or $1.5 \mathrm{~mL}$ of each hydroalcoholic extract of propolis (propolis final concentration of 4.5 and $9 \mathrm{mg} \mathrm{mL}^{-1}$ ). When $0.75 \mathrm{~mL}$ of propolis was added, the volume was brought up to10 $\mathrm{mL}$ with sterile distilled water. Falcon tubes with only YPD or with YPD plus ethanol:water $(70: 30 \mathrm{v} / \mathrm{v})$ were used as control. The Falcon tubes were incubated at $30^{\circ} \mathrm{C}$ for $48 \mathrm{~h}$ at 160 rpm. The yeast viability was assessed by staining the samples with sodium citrate-methylene blue solution (LEE et al., 1981) and counting the cells in a Neubauer chamber. The assay was carried out in a completely randomised design with three replicates per treatment. For each yeast strain, the logarithmic reduction in growth was calculated considering the $\log$ of the cell number at $48 \mathrm{~h}$ of cultivation for each propolis type and concentration in relation to the $\log$ of the cell number at $48 \mathrm{~h}$ of cultivation in the control treatment without propolis (only YPD).

The results showed that the absorption spectra of hydroalcoholic extracts from Argentinean propolis were in the wavelength range expected: from 200 to $600 \mathrm{~nm}$ (Figure 1). UV spectrograms showed that all the samples displayed a maximum absorbance range between 250 and $300 \mathrm{~nm}$, with a main absorption peak at $295 \mathrm{~nm}$. The existence of an absorption maximum at $295 \mathrm{~nm}$ is indicative of an important biological activity, due to the content of flavonoid compounds (SFORCIN; BANKOVA, 2011). The UV-VIS absorbance spectra were also consistent with data recorded from other propolis samples from Argentina (BEDASCARRASBURE et al., 2006).

The final concentrations of the soluble compounds of the propolis samples in the hydroalcoholic solutions were as follows: $63 \mathrm{mg}$ $\mathrm{mL}^{-1}$ for Río Colorado (Río Negro Province), $35 \mathrm{mg}$ $\mathrm{mL}^{-1}$ for Luján de Cuyo (Mendoza Province), $60 \mathrm{mg}$ $\mathrm{mL}^{-1}$ for Bahía Blanca (Buenos Aires Province) and $90 \mathrm{mg} \mathrm{mL}^{-1}$ for Carmen de Patagones (Buenos Aires Province). Talero et al. (2012) described that 70\% $(\mathrm{v} / \mathrm{v})$ ethanol extractions had average values of dry extracts lower than those obtained with $96 \%(\mathrm{v} / \mathrm{v})$ ethanol. However, the choice of hydroalcoholic solution is supported by the studies of Silva Frozza et al. (2013), which indicated that this extractant is able to solubilize phenols and different bioactive compounds in considerable quantities, and that it is less toxic than other solvents. Moreover, Sforcin and Bankova (2011) encouraged the idea that the most often utilised solvent is a diluted solution of ethanol in water because it was found to extract most of the active components from propolis, but not from waxes. 
In the qualitative in vitro assay, the yeasts showed strong growth in both control samples in all dilutions tested $\left(10^{-1}, 10^{-3}\right.$ and $10^{-5}$, data not shown). The results of this qualitative screening clearly demonstrated that the alcoholic solution utilised as an extractant in the propolis solutions, ethanol:water $(70: 30, v / v)$, did not inhibit the yeast growth. These results are in agreement with studies from other authors (CIGUT et al., 2011; GALLEZ et al., 2014).

Table 1 presents the results of the qualitative in vitro assay of the antimicrobial activity of propolis against $D$. bruxellensis and $S$. cerevisiae. The results clearly revealed that the four hydroalcoholic extracts of propolis inhibited completely the growth of $D$. bruxellensis at concentrations of $0.225,0.45$ and 0.9 $\mathrm{mg} \mathrm{mL} \mathrm{m}^{-1}$. This yeast grew poorly at $0.1125 \mathrm{mg} \mathrm{mL}^{-1}$ of propolis and only at $10^{-1}$ dilution. The results were very different for $S$. cerevisiae: concentrations of 0.45 and $0.9 \mathrm{mg} \mathrm{mL}^{-1}$ of propolis were completely inhibitory to the growth of $S$. cerevisiae. However, the lowest concentrations tested, $0.1125 \mathrm{mg} \mathrm{mL}^{-1}$ of propolis, did not interfere with the growth of this yeast in all dilutions. Moreover, the observed growth was similar to that of the control without propolis. At $0.225 \mathrm{mg} \mathrm{mL}^{-1}$ of propolis, this yeast exhibited a strong growth at $10^{-1}$ and $10^{-3}$ dilutions. These results demonstrated the differences in behaviours between the yeasts when they were grown in YPD with different concentrations of propolis, showing that $S$. cerevisiae was inhibited by propolis at higher concentrations than were needed to inhibit D. bruxellensis growth. There was no difference in growth inhibition regarding the origin of the propolis for either yeast. Cigut et al. (2011) studied the antioxidative activity of propolis in vivo using the yeast $S$. cerevisiae. They demonstrated that propolis did not have a negative effect on this yeast. They also found that yeast cells exposed to $96 \%$ ethanolic extracts of propolis showed decreased intracellular oxidation.

Table 1. Antimicrobial activity of propolis at different concentrations against $D$. bruxellensis and $S$. cerevisiae in the qualitative in vitro assay. Growth evaluation: 0 (no growth); + (weak growth); ++ (strong growth); +++ (growth similar to the control without propolis).

\begin{tabular}{|c|c|c|c|c|c|c|c|c|c|c|c|c|c|c|c|c|}
\hline \multirow{3}{*}{ Yeast } & \multicolumn{16}{|c|}{ Argentinean propolis } \\
\hline & \multicolumn{4}{|c|}{$\begin{array}{l}\text { Río Colorado } \\
\left(\mathrm{mg} \mathrm{mL}^{-1}\right)\end{array}$} & \multicolumn{4}{|c|}{$\begin{array}{l}\text { Carmen de Patago- } \\
\text { nes }\left(\mathrm{mg} \mathrm{mL}^{-1}\right)\end{array}$} & \multicolumn{4}{|c|}{$\begin{array}{c}\text { Bahía Blanca } \\
\left(\mathrm{mg} \mathrm{mL}^{-1}\right)\end{array}$} & \multicolumn{4}{|c|}{$\begin{array}{l}\text { Luján de Cuyo } \\
\qquad\left(\mathrm{mg} \mathrm{mL}^{-1}\right)\end{array}$} \\
\hline & $\stackrel{n}{\Xi}$ & $\stackrel{\widetilde{N}}{\tilde{\Xi}}$ & $\stackrel{n}{\stackrel{0}{0}}$ & $\dot{\theta}$ & $\stackrel{\mathscr{a}}{\Xi}$ & $\stackrel{n}{\tilde{N}}$ & $\stackrel{10}{0}$ & $\ddot{\theta}$ & $\stackrel{2}{\dddot{\Xi}}$ & 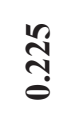 & $\stackrel{n}{0}$ & $\hat{\theta}$ & $\stackrel{\mathscr{Z}}{\Xi}$ & $\underset{\tilde{N}}{\stackrel{\sim}{0}}$ & $\stackrel{10}{9}$ & gे \\
\hline Dekkera bruxellensis & +1 & 0 & 0 & 0 & +1 & 0 & 0 & 0 & +1 & 0 & 0 & 0 & $++^{1}$ & 0 & 0 & 0 \\
\hline Saccharomyces cerevisiae & $+++^{2}$ & $++^{3}$ & 0 & 0 & $+++^{2}$ & $++^{3}$ & 0 & 0 & $+++^{2}$ & $++^{3}$ & 0 & 0 & $+++^{2}$ & $+++^{3}$ & 0 & 0 \\
\hline
\end{tabular}

${ }^{1}$ at $10^{-1}$ dilution only; ${ }^{2}$ in all dilutions; ${ }^{3}$ at $10^{-1}$ and $10^{-3}$ dilutions.

Two hydroalcoholic extracts of propolis were selected for the quantitative in vitro assay, considering the different geographical origin of the propolis sample (Figure 1): Luján de Cuyo (Mendoza Province) and Río Colorado (Río Negro Province). As previously mentioned, propolis properties depend on its chemical nature, which is strongly related to the flora surrounding the hive (SFORCIN; BANKOVA, 2011).
In this assay, higher concentrations of propolis ( 4.5 and $9 \mathrm{mg} \mathrm{mL}^{-1}$ ) were utilised due to the usage of liquid medium instead of solid medium. Figure 2 displays the results of the quantitative evaluation assay of propolis as an antimicrobial agent against D. bruxellensis and S. cerevisiae during $48 \mathrm{~h}$ of cultivation. There was less inhibition using both types of propolis on $S$. cerevisiae than on $D$. bruxellensis. After the incubation with propolis, 
the cell number of $D$. bruxellensis at the lowest concentration (4.5 $\mathrm{mg} \mathrm{mL}^{-1}$ ) decreased 1.52 and 1.85 log cycles for Luján de Cuyo (Mendoza Province) and Río Colorado (Río Negro province) propolis samples, respectively. For $S$. cerevisiae, the decrease varied from 0.48 to $0.76 \log$ cycles for Río Colorado propolis, and from 0.48 to $0.58 \log$ cycles for Luján de Cuyo propolis, depending on the concentration. These results clearly demonstrated the selectivity of propolis on the yeast species, especially considering that the most sensitive is the contaminant strain, D. bruxellensis. No noteworthy differences between the propolis samples regarding the growth inhibition of both yeasts were observed.

Figure 2. Logarithmic reduction in cell number of Dekkera bruxellensis and Saccharomyces cerevisiae in the quantitative in vitro assay with different concentrations of hydroalcoholic extracts of propolis from Argentina sites.

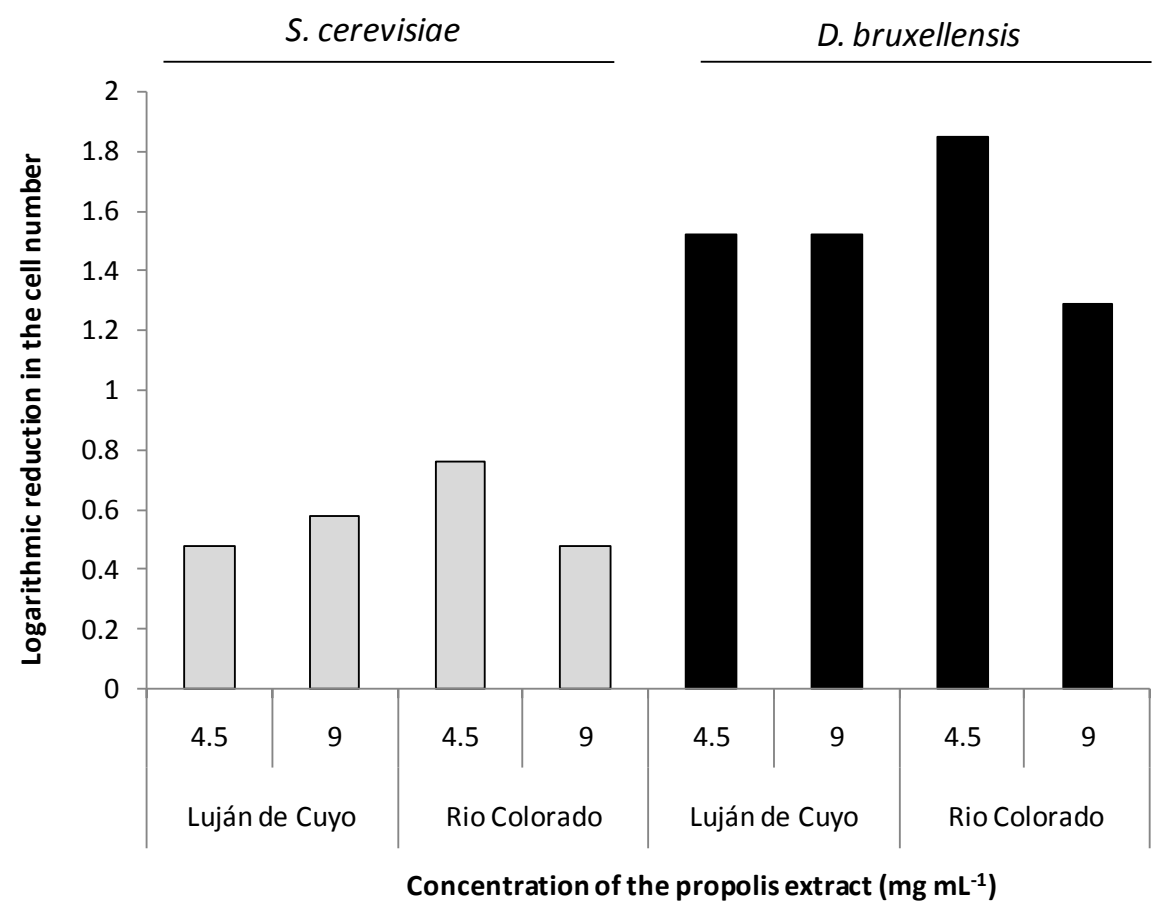

It is interesting to note that the number of viable cells of Dekkera and Saccharomyces after $48 \mathrm{~h}$ of incubation in the control treatment consisting of YPD with ethanol:water was not remarkably different from the control consisting of YPD without ethanol (data not shown). Thus, these data confirmed that the antimicrobial activity was due to the presence of bioactive compounds in the hydroalcoholic extracts from Argentinean propolis and not due to the alcohol inhibition, as it was previously described in the qualitative assay.

Other researchers have found similar results regarding $S$. cerevisiae when studying different substances to control contaminants during ethanolic fermentation. Madaleno et al. (2016) evaluated the initial and final yeast viability when antimicrobials as hop extract, oregano essential oil and chlorine dioxide were utilised during the fermentation process to control bacterial growth. They found that the viability of $S$. cerevisiae did not change significantly with any antimicrobial substance, indicating that treatments used at their recommended doses do not eliminate yeast cells from the fermentation process. On the other hand, Mutton et al. (2014) evaluated the efficiency of brown and green propolis to control bacterial contamination in the production of 
sugarcane spirit. They observed a reduction in the number of bacterial contaminants with the natural biocides, which did not affect the viability of yeast cells.

In conclusion, our results from both assays demonstrated the selectivity of propolis on the yeast species, especially considering that the contaminant strain $D$. bruxellensis is the most sensitive. This indicates the good prospect of using propolis as a nonconventional strategy to control the growth of D. bruxellensis at a propolis concentration of 4.5 $\mathrm{mg} \mathrm{mL} \mathrm{m}^{-1}$ of propolis. In addition, $S$. cerevisiae, the most important starter yeast in industrial alcoholic fermentation, was not substantially affected by propolis. Further studies are necessary to evaluate the utilisation of propolis as a nonconventional strategy in similar conditions to those of industrial production, such as the fermentative process with cell recycling and addition of the product in fermentation tanks or during the cell treatment step.

\section{Acknowledgements}

The authors are thankful to the CIC (Comision de Investigaciones Científicas, Argentina) and FAPESP (Fundação de Amparo a Pesquisa do Estado de São Paulo, Brazil, process 2014/17794-2) for the financial support of the research work. We also want to thank AUGM (Asociación de Universidades del Grupo Montevideo) for providing a fellowship to Leticia A. Fernández.

\section{References}

BADIN, F. Biocidas naturais e seus reflexos sobre contaminantes na produção de etanol. 2010. Dissertação (Mestrado em Microbiologia Agropecuária) Universidade Estadual Paulista, Jaboticabal.

BARATA, A.; CALDEIRA, J.; BOTELHEIRO, R.; PAGLIARA, D.; MALFEITO-FERREIRA, M.; LOUREIRO, V. Survival patterns of Dekkera bruxellensis in wines and inhibitory effect of sulphur dioxide. International Journal of Food Microbiology, Amsterdam, v. 121, n. 2, p. 201-207, 2008. DOI: 10.1016/j.ijfoodmicro.2007.11.020
BASSI, A. P. G.; PARALUPPI, A. L.; REIS, V. R.; CECCATO-ANTONINI, S. R. Potassium metabisulphite as a potential biocide against Dekkera bruxellensis in fuel ethanol fermentations. Letters in Applied Microbiology, London, v. 60, n. 3, p. 248-258, 2014. DOI: 10.1111/ lam. 12363

BASSI, A. P. G.; SILVA, J. C. G.; REIS, V. R.; CECCATO-ANTONINI, S. R. Effects of single and combined cell treatments based on low $\mathrm{pH}$ and high concentrations of ethanol on the growth and fermentation of Dekkerabruxellensis and Saccharomyces cerevisiae. World Journal of Microbiology and Biotechnology, Amsterdam, v. 29, n. 9, p. 1661-1676, 2013. DOI: 10.1007/s11274-013-1329-x

BEDASCARRASBURE, E.; MALDONADO, L. M.; FIERRO MORALES, W.; ALVAREZ, A. R. Propóleos. caracterización y normalización de propóleos argentinos. Revisión y actualización de composición y propiedades. Buenos Aires: Ediciones Magna, 2006. 218 p.

CECCATO-ANTONINI, S. R. Convention alandnonc onvention alstrategies for controlling bacterial contamination in fuelethanol fermentations. World Journal of Microbiology and Biotechnology, Amsterdam, v. 34 , n. 80 , p. $1-11,2018$. DOI: $10.1007 / \mathrm{s} 11274-018-$ $2463-2$

CIGUT, T.; POLAK, T.; GAŠPERLIN, L.; RASPOR, P.; JAMNIK, P. Antioxidative activity of propolis extract in yeast cells. Journal of Agriculturaland Food Chemistry, Washington, v. 59, n. 21, p. 11449-11455, 2011. DOI: $10.1021 / \mathrm{jf} 2022258$

GALLEZ, L. M.; FERNÁNDEZ, L. A.; CIBANAL, I. L. Propóleos: su uso como biofungicida agrícola. Ciencia Hoy, Buenos Aires, v. 26, n. 155, p. 55-59, 2017.

GALLEZ，L. M.; KIEHR, M.; FERNÁNDEZ，L.; DELHEY, R.; STIKAR, D. Antifungal activity in vitro of propolis solutions from Argentina against two plant pathogenic fungi: Didymellabryoniae and Rhizotocniasolani. Journal of Apicultural Research, London, v. 53, n. 4, p. 438-440, 2014. DOI: 10.3896/ IBRA.1.53.4.08

GÓMEZ-RIVAS，L.; ESCUDERO-ABARCA，B. I.; AGUILAR-USCANGA, M. G.; HAYWARD-JONES, P. M.; MENDOZA, P.; RAMIREZ, M. Selective antimicrobial action of chitosan against spoilage yeasts in mixed culture fermentations. Journal of Industrial Microbiology and Biotechnology, Fairfax, v. 31, n. 1, p. 16-22, 2004. DOI: 10.1007/s10295-004-0112-2

HERIGSTAD, B.; HAMILTON, M.; HEERSINK, J. How to optimize the drop plate method for enumerating bacteria. Journal of Microbiology Methods, Amsterdam, 
v. 44 , n. 2 , p. $121-129$, 2001. DOI: $10.1016 / \mathrm{S} 0167-$ 7012(00)00241-4

LEE, S. S.; ROBINSON, F. M.; WANG, H. Y. Rapid determination of yeast viability. Biotechnology and Bioengineering, Hoboken, v. 11, p. 641-649, 1981.

MADALENO, L. L.; MINARI, G. D.; ANNUNZIO, F. R.; CARVALHO, M. R.; BOSSA JUNIOR, G. R.; SALES, D. C.; FRIGIERI, M. C. Use of antimicrobials for contamination control during ethanolic fermentation. Cientifica, Jaboticabal, v. 44, n. 2, p. 226-234, 2016. DOI: $10.15361 / 1984-5529.2016 v 44 n 2 p 226-234$

MENEGHIN, M. C.; BASSI, A. P. G.; CODATO, C. B.; REIS, V. R.; CECCATO-ANTONINI, S. R. Fermentative and growth performances of Dekkerabruxellensisin different batch systems and the effect of initial low cell counts in co cultures with Saccharomyces cerevisiae. Yeast, Chichester, v. 30, n. 8, p. 295-305, 2013. DOI: 10.1002/yea.2959

MUTTON, M. J. R.; OLIVEIRA FILHO, J. H.; COSTA, G. H. G.; ROVIERO, J. P.; FREITA, L. A. Green and brown propolis: efficient natural biocides for the control of bacterial contamination of alcoholic fermentation of distilled beverage. Food Science and Technology, Campinas, v. 34, n. 4, p. $767-772$, 2014. DOI: 10.1590/1678-457X.6469

SFORCIN, J. M.; BANKOVA, V. Propolis: is there a potential for the development of new drugs? Journal of Ethnopharmacology, Shannon, v. 133, n. 2, p. 253-260, 2011. DOI: $10.1016 /$ j.jep.2010.10.032
SILVA FROZZA, C. O. da; GARCIA, C. S. C.; GAMBATO, G.; SOUZA, M. D. O. de; SALVADOR, M.; MOURA, S.; PADILHA, F. F.; SEIXAS, F. K.; COLLARES, T.; BORSUK, S.; DELLAGOSTIN, O. A.; HENRIQUES, J. A. P.; ROESCH-ELY, M. Chemical characterization, antioxidant and cytotoxic activities of Brazilian red propolis. Food and Chemical Toxicology, London, v. 52, p. 137-142, 2013. DOI: 10.1016/j. fct.2012.11.013

SOUZA-LIBERAL, A. T.; BASILIO, A. C. M.; MONTE RESENDE, A.; BRASILEIRO, B. T. V.; SILVA FILHO, E. A. da; MORAIS, J. O. F. de; SIMÕES, D. A.; MORAIS JÚNIOR, M. A. Identification of Dekkera bruxellensis as a major contaminant yeast in continuous fuel ethanol fermentation. Journal of Applied Microbiology, London, v. 102 , n. 2 , p. $538-547,2007$. DOI: $10.1111 /$ j.13652672.2006.03082.x

TALERO, C.; HERNÁNDEZ, D.; FIGUEROA, J. Calidad microbiológica de propóleos crudo y sólidos solubles de extractos de propóleos de Apis mellifera en Colombia. Revista de la Facultad de Medicina Veterinaria y de Zootecnia, Bogotá, v. 59, n. 2, p. 109118, 2012.

VIUDA-MARTOS, M.; RUIZ-NAVAJAS, Y; FERNÁNDEZ-LÓPEZ, J.; PÉREZ-ALVAREZ, J. A. Functional properties of honey, propolis, and royal jelly. Journal of Food Science, Chicago, v. 73, n. 9, p. 117-24, 2008. DOI: $10.1111 /$ j.1750-3841.2008.00966.x 